\title{
Growth and Feasibility of Solar Irrigation Pump in Rajasthan, India: An Economic Perspective
}

\author{
Yash Gautam*, O.P. Singh and P.K. Singh \\ Department of Agricultural Economics, Institute of Agricultural Sciences, BHU, Varanasi, India
}

"Corresponding author: yashgautam37@gmail.com (ORCID ID: 0000-0003-1142-3511)

Paper No. 869

Received: 24-08-2020

Revised: $17-11-2020$

Accepted: 06-12-2020

\begin{abstract}
Agriculture plays an important role in the Indian economy. The agriculture sector has seen consistent and significant growth in terms of technology and innovation, which has helped India to become a food exporter. However, past initiatives focussed on improving production and environmental aspect were neglected. Now, government is formulating policies and initiatives that would help in increasing agriculture production along with sustainable development. Promotion of solar irrigation pump is among one of those policies. Provision of heavy subsidies and schemes (JNNSM, KUSUM, etc.) on the adoption of solar pumps have increased their affordability. Because of the increased affordability of solar pumps after subsidies, the popularity of solar pumps has increased in Rajasthan, which has resulted in an increased rate of adoption. Considering the role of solar pumps in current scenario and that of future, this study was conducted to analyze the economic viability and costs incurred in solar pump installation. Payback period, NPV, BCR, and IRR were used in the analysis.

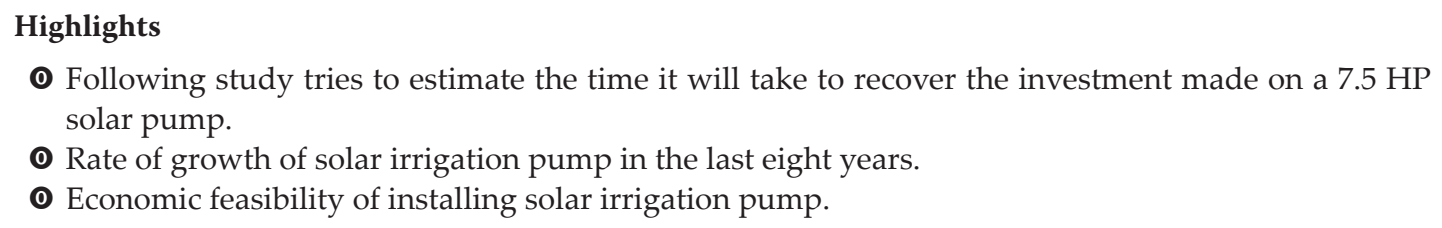

Keywords: Payback period, net present worth, benefit-cost ratio and internal rate of return, economic viability, solar irrigation pump

Agriculture plays an important role in the Indian economy. It has a significant contribution to country's GDP and employment generation. Though India is no longer an agrarian economy, some 70 percent of its rural households still depend primarily on agriculture for their livelihood (FAO 2018).

Since independence, India has witnessed significant growth in terms of food production and improvement in technology. Past strategies focused on the development of the agriculture sector and improving food security. These strategies involved using better technology and varieties for an increase in productivity, increased use of agrochemicals, fertilizer, quality seed, and irrigation, incentives in the form of remunerative prices for some crops and subsidy policies for farm inputs, public investments for the agriculture sector, and facilitating institutions for the improvement of agriculture.

The strategies proved to be fruitful, as the country was able to tackle the severe food shortages that emerged during mid-1960s. With the Green Revolution, food production in India multiplied

How to cite this article: Gautam, Y., Singh, O.P. and Singh, P.K. 2020. Growth and Feasibility of Solar Irrigation Pump in Rajasthan, India: An Economic Perspective. IJAEB, 13(4): 461-467.

Source of Support: None; Conflict of Interest: None 
by 3.7 times, whereas the population multiplied by 2.55 times during the same time (NITI AYOG 2017). However, none of the strategies were primarily focused on increasing farmers' income and welfare. Hence, the net result was that farmers' income remained low, which is evident from the incidence of poverty among farm households. According to NSSO data on Consumption Expenditure Survey for the year 2011-12, more than one-fifth of rural households with self-employment in agriculture as their principal occupation had income less than the poverty line. This can cause serious adverse effects on the future of agriculture of the country. In this background, the goal set by Prime Minister Shri Narendra Modi to double farmers' income by 2022-23 is central to promote farmers' welfare, reduce agrarian distress and bring uniformity among the income of farmers and those working in non-agricultural professions.

There are various areas in agriculture that can be exploited to increase farmers' income but what is important is that all the initiatives and efforts should go hand-in-hand with the environment. From past experience, we had learned that when the focus was on increasing food production, environmental impacts were highly neglected. The best example is reduced water table and degraded soil health in Punjab.

According to FAO, agriculture in India still remains largely rain-fed $(60 \%)$ and vulnerable to the vagaries of the monsoon, and so are the fates of millions of Indian farmers. To overcome this problem, farmers started using diesel water pumps and electric water pumps to irrigate their fields. This, although reduced the dependence of farmers on monsoon to some extent but increased their cost of production. With time, cost of diesel and electricity increased, which further reduced the returns of farmers. India uses more than 4 billion liters of diesel and around 85 million tons of coal per annum to support water pumping for irrigation. If one million diesel pumps were replaced with solar pumps, then it would result in diesel use mitigation of approximately nine billion liters over the life cycle of solar pumps. It would save ₹ 8,400 Crores on diesel subsidy and reduce $\mathrm{CO}_{2}$ emission up to 25.3 million tonnes. Foreign exchange savings of USD 300 million per annum on diesel imports for replacement of one million diesel pumps translating into forex savings of USD 4.5 billion over pump life (KPMG, 2014).
With the increase in population, urbanization and development in India, the demand for energy has increased in recent years. Today, India relies heavily on fossil fuels to meet its energy requirements. Around $69.5 \%$ of the total power is generated by thermal power plants (MoP 2020). In India, electricity generated by burning fossil fuels contributes $37.8 \%$ of the total greenhouse gasses released into the atmosphere (GoI 2016). The burning of fossil fuels increases carbon-dioxide emission, which is a major contributor to the climate change crisis today (Schock et al. 2007). In 2016, the World Health Organization (WHO) released a report in which 11 Indian cities have occupied positions in the list of top 25 polluted cities of the world (WHO 2017). Currently, India is the third-largest Greenhouse gas emitter in the world after China and the USA.

Renewable energy sources are capable solving the problem of sustainable development associated with fossil fuel-based power plants as these energy sources are unlimited, eco-friendly, and provides energy with negligible emissions of air pollutants and greenhouse gases (Singal 2007). In order to achieve a sustainable development approach that promotes both economic and environmental objectives, the National Action Plan for Climate Change (NAPCC) was launched on $30^{\text {th }}$ June 2008 in India. In subsequent efforts, Jawaharlal Nehru National Solar Mission (JNNSM) was launched on the $11^{\text {th }}$ January, 2010. Its objective was to establish India as a global leader in solar energy. During the presentation of Union Budget 2018-19, Central Government had announced the Kisan Urja Suraksha Evam Utthaan Mahabhiyan (KUSUM) Scheme for farmers under which government will provide subsidy for setting up of solar power plants on their barren land. Under KUSUM scheme, government will set up 10,000 MW solar power plants on the barren lands of farmers.

Crop production under the solar irrigation system provides higher income as compared to crop production under the diesel irrigation system. It is because the irrigation charges or diesel charges in the diesel irrigation system are saved in the solar irrigation system. Cost of cultivation of groundnut under the solar irrigation system was ₹ 74,415.29, whereas the gross return obtained by the farmer was ₹ $1,00,445.41$. Hence, the net income was ₹ $30,350.31$ (Gautam and Singh 2020). Similarly, the net income 
of farmers who produced pearl millet under solar irrigation system was higher as compared to diesel irrigation system (Gautam and Singh 2020).

Adoption of solar irrigation pump is not only good for the environment but also economically feasible. The payback period of $5 \mathrm{HP}$ solar irrigation pumps was 2.53 years, $t$ present net worth was ₹ 3,64,687.52, benefit-cost ratio was 3.94 , and IRR was 34.03 percent. A similar result was observed in the case of $3 \mathrm{HP}$ solar irrigation pump in Jaipur Rajasthan, where the payback period, NPV, BCR, and IRR were 2.08 years, $₹ 3,82,404.05,4.6$, and 35.06 percent respectively (Gautam 2020).

With the implementation of KUSUM scheme and other subsidies under Union Budget 2018 and the state budget of Rajasthan, the popularity of solar pumps in the farming community has increased.

\section{METHODOLOGY}

The study was based on primary data collected with the help of a survey schedule. Rajasthan was purposively selected because it receives the highest annual global radiation, and the installation of solar irrigation pumps was maximum. Jaipur was selected purposively because the number of solar irrigation pumps installed was maximum in the district. Respondents were selected with the snowball sampling method. Compound growth rate was used to estimate the rate of adoption of solar irrigation pump during 2010-11 to 2018-19. To estimate the cost of installation, all fixed and variable costs involved in the installation of solar irrigation pump were worked out starting from the purchase of pumps to the installation of pump along with the cost of accessories. To examine the economic viability of solar irrigation pumps, the following criteria were employed:

\section{(a) Payback period}

Payback period (years) $=$ Investment of the project /Annual net cash revenue

\section{(b) Net Present Worth}

$$
\begin{aligned}
N P W=\frac{P_{1}}{(1+i)^{t_{1}}} & +\frac{P_{2}}{(1+i)^{t_{2}}} \\
& \begin{aligned}
+\frac{P_{3}}{(1+i)^{t_{3}}} \ldots . .+\frac{P_{n}}{(1+i)^{t_{n}}}-C
\end{aligned}
\end{aligned}
$$

Where,

$P=$ Net cash flow in $\mathrm{n}^{\text {th }}$ year (years); $i=$ Discount rate; $t=$ time period (years); $C=$ Initial cost of investment.

\section{(c) Internal rate of Return}

\section{IRR}

$=[$ Lower discount rate $]$

+ [Difference between the two discount rate]

$\times\left[\begin{array}{c}\text { Present worth of cash flow at lower discount rate } \\ \text { Absolute difference between the present worths of the cash } \\ \text { flow at the two discount rates }\end{array}\right]$

\section{(d) Benefit - Cost ratio}

$$
B-C \text { ratio }=\frac{\sum_{t=1}^{n} \frac{B_{t}}{(1+r)^{n}}}{\sum_{t=1}^{n} \frac{C_{t}}{(1+r)^{n}}}
$$

Where,

$B_{t}=$ Present worth of cash flow; $C_{t}=$ Present worth of Cost; $r=$ rate of interest; $n=$ number of years.

\section{RESULTS AND DISCUSSION}

\section{Growth rate of solar irrigation pump installation}

In 2010-11, the total number of solar irrigation pumps installed in Rajasthan was 31, and by the end of 2018-19, the number of solar pumps increased to 10,575 . The growth trend analysis of solar irrigation pump installation suggests that it was augmenting with a compound growth rate of 77.4 percent per annum during the period of study as represented in appendix Table 1.

Table 1: Compound growth rate of solar irrigation pumps in Rajasthan

\begin{tabular}{ll}
\hline & $\begin{array}{l}\text { Period of study } \\
\text { Particulars }\end{array}$ \\
& $\mathbf{1 9 1 0 - 1 1}$ to 2018- \\
\hline Number of pumps in beginning year & 31 \\
Number of pumps in end year & 10575 \\
No. of observations & 09 \\
Compound growth rate & $77.4^{*}$ \\
$\mathrm{R}^{2}$ & 0.807 \\
\hline
\end{tabular}

*: indicate significant at 5 percent level of significance.

The increase in the solar irrigation pump during the study period can be attributed to the efforts of the 
government in its promotion through the Jawaharlal Nehru National Solar Mission (JNNSM), also known as National Solar Mission, which was launched on the $11^{\text {th }}$ January 2010. In addition to JNNSM, several new schemes and subsidy programmes were launched by the government, which made solar irrigation pumps a more attractive investment. Introduction of new companies in the solar industry leads to the improvement in technology and reduction in the cost of manufacturing solar irrigation pumps and their accessories, which decreased their cost over the course of time.

\section{Cost of installation}

The average total cost of installation of $7.5 \mathrm{HP}$ solar irrigation pump in the study area was ₹ 4,97,220, out of which farmer's share was 59.54 percent, which amounted to ₹ 2,96,084. ₹ 2,01,136 was provided in the form of subsidy, which contributed to 40.45 percent of the total cost. The total cost of the solar irrigation pump included installation charges and the cost of the solar pump kit. One solar kit comprised of solar panel, solar inverter, solar battery, junction box, DC cable, AC cable, MC4 connector, fasteners, cable tie, crimping tool, earthing kit and lighting arrestor. Farmers were also eligible for bank finance for making the purchase. Financing policies varied from bank to bank.

\section{Cost of replacement}

Replacing an existing diesel pump with a 7.5 solar irrigation pump required an amount that was equal to the cost of a solar irrigation pump setup, assuming that the salvage value of the old diesel pump is zero. None of the parts of the diesel pump was used in the solar irrigation pump. It means, when a diesel irrigation pump was replaced with a $7.5 \mathrm{HP}$ solar irrigation pump, then its replacement cost was equal to ₹ $4,97,220$.

\section{Economic viability}

Earlier, farmers were using $7 \mathrm{HP}$ diesel pump for irrigation. The average total consumption of diesel used as fuel for running diesel irrigation pump was ₹ 41,937.89 litersper year per farmer in the sample (Gautam 2020). Later, farmers replaced diesel irrigation pump with 7.5 solar irrigation pump. When farmers shifted to solar irrigation pump from diesel irrigation pumps, they didn't have to pay for diesel, and hence, expenditure incurred on diesel was saved. Hence, the incremental benefit was equal to the total expenditure on diesel, which was, in this case, ₹ $41,937.89$. The economic viability of the 7.5 HP solar irrigation pump was calculated with the help of this incremental benefit.

\section{Payback period}

Total cost of a $7.5 \mathrm{HP}$ solar pump was ₹ 4,97,220. Farmer's share was ₹ 2,96,084. It was estimated that the investment made on a $7.5 \mathrm{HP}$ solar irrigation pump would be recovered in 7.06 years.

\section{Net Present Worth}

The economic benefit for the installation of solar irrigation pump was diesel saving. Total cost of diesel saving was estimated to be 41937.89 . The repair and maintenance cost of a solar pump was ₹ 3000 per year. Due to the warranty cover provided by the company, the farmer didn't have to pay anything first 4 years of maintenance. Thereafter, the farmer had to pay ₹ 3000 per year for its repair and maintenance. At 7 percent discount factor, the net present worth was estimated to be ₹ 1,87,213.06. The result has been presented in appendix Table 2 .

\section{Internal Rate of Return (IRR)}

Table 3 in appendix shows the calculation of the internal rate of return of a $7.5 \mathrm{HP}$ solar irrigation pump. Share of a farmer in the total cost of a $7.5 \mathrm{HP}$ solar irrigation pump was ₹ 2,96,084.47. The economic benefit for the installation of solar irrigation pump was diesel saving. The total cost of diesel saving was estimated to be 41937.89 . At a lower discount rate of 7 percent, present net worth was $₹ 1,87,213.06$, and at a higher discount rate of 30 percent, NPW was $-91,649.55$. The internal rate of return was estimated to be 22.44 percent.

\section{Benefit cost ratio}

The total cost of $7.5 \mathrm{HP}$ solar irrigation pump was $₹ 4,97,220.93$. Out of total cost, Government provides a subsidy of ₹ $2,01,136.46$. The share of a farmer in the total cost of a $7.5 \mathrm{HP}$ solar irrigation pump was ₹ $2,96,084.47$. The economic benefit for installation of solar irrigation pump was diesel saving. The present worth of gross return for 7.5 HP pump was $₹ 4,88,726.63$, and the present worth of cost 
Table 2: Estimation of Net Present Value (NPV) for 7.5 HP Solar Pump

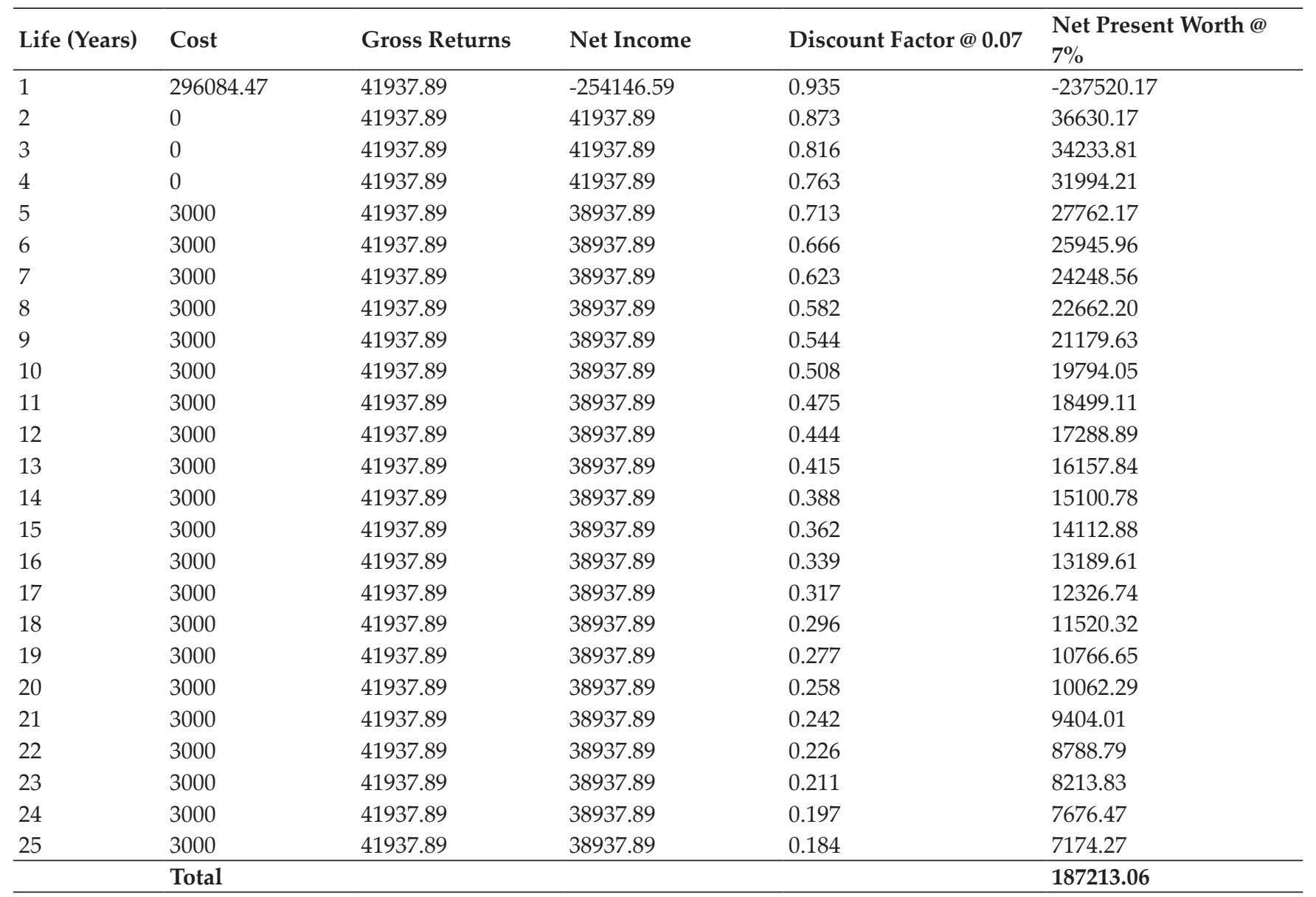

Table 3: Estimation of Internal Rate of Return (IRR) for 7.5 HP Solar Pump

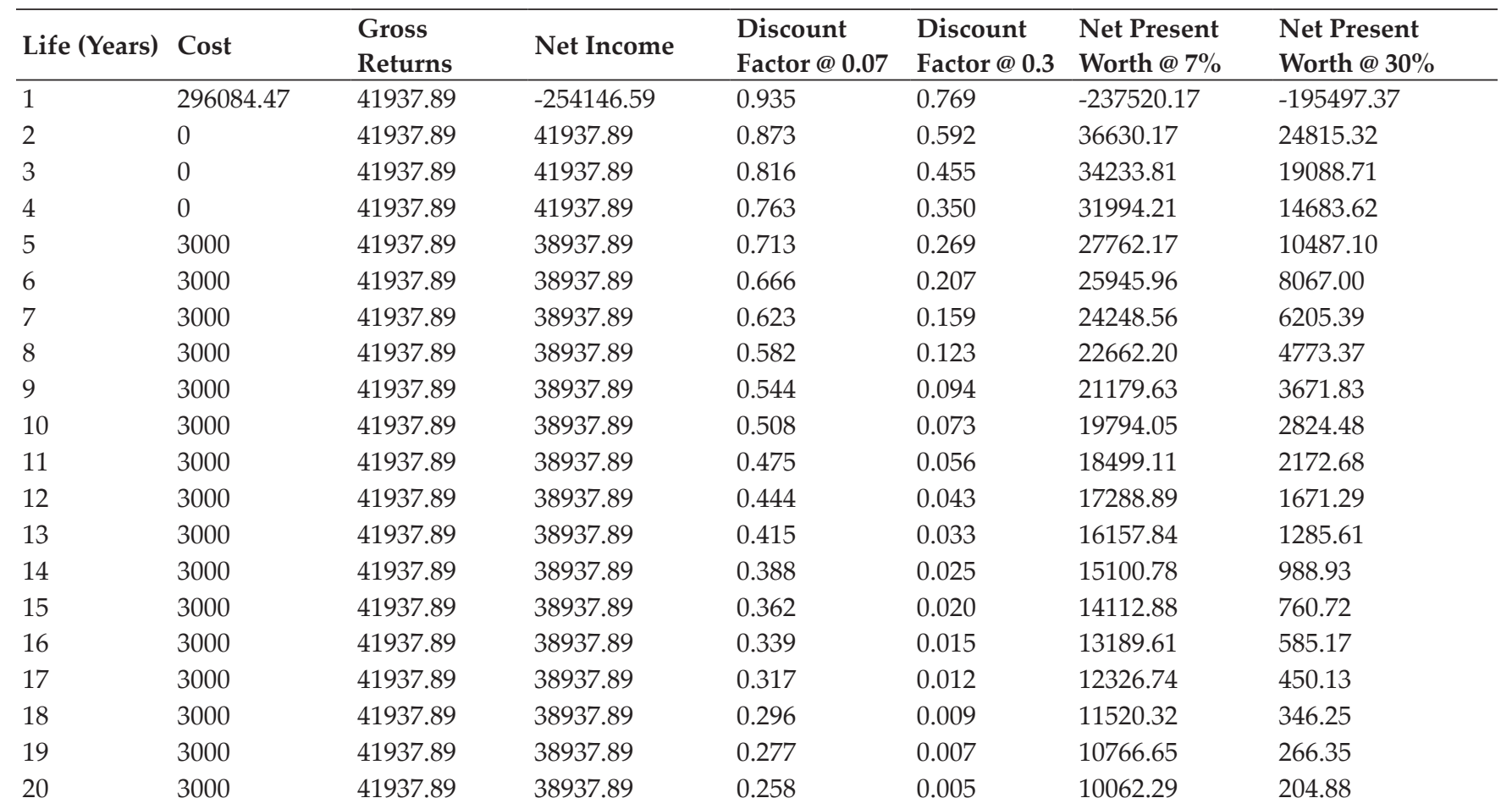




\begin{tabular}{llllllll}
21 & 3000 & 41937.89 & 38937.89 & 0.242 & 0.004 & 9404.01 & 157.60 \\
22 & 3000 & 41937.89 & 38937.89 & 0.226 & 0.003 & 8788.79 & 121.23 \\
23 & 3000 & 41937.89 & 38937.89 & 0.211 & 0.002 & 8213.83 & 93.26 \\
24 & 3000 & 41937.89 & 38937.89 & 0.197 & 0.002 & 7676.47 & 71.74 \\
25 & 3000 & 41937.89 & 38937.89 & 0.184 & 0.001 & 7174.27 & 55.18 \\
\hline \multicolumn{7}{c}{} \\
\hline
\end{tabular}

Table 4: Estimation of Benefit cost ratio (B:C Ratio) for 7.5 HP Solar Pump

\begin{tabular}{llllll}
\hline Life (Years) & Cost & Gross Returns & $\begin{array}{l}\text { Discount Factor } \\
\text { @ 0.07 }\end{array}$ & $\begin{array}{l}\text { Present worth of Gross } \\
\text { return @ 7 \% }\end{array}$ & $\begin{array}{l}\text { Present Worth of Cost } \\
\text { @ 7 \% }\end{array}$ \\
\hline 1 & 296084.47 & 41937.89 & 0.935 & 39194.29 & 276714.46 \\
2 & 0 & 41937.89 & 0.873 & 36630.17 & 0.00 \\
3 & 0 & 41937.89 & 0.816 & 34233.81 & 0.00 \\
4 & 0 & 41937.89 & 0.763 & 31994.21 & 0.00 \\
5 & 3000 & 41937.89 & 0.713 & 29901.13 & 2138.96 \\
6 & 3000 & 41937.89 & 0.666 & 27944.98 & 1999.03 \\
7 & 3000 & 41937.89 & 0.623 & 26116.81 & 1868.25 \\
8 & 3000 & 41937.89 & 0.582 & 24408.23 & 1746.03 \\
9 & 3000 & 41937.89 & 0.544 & 22811.43 & 1631.80 \\
10 & 3000 & 41937.89 & 0.508 & 21319.09 & 1525.05 \\
11 & 3000 & 41937.89 & 0.475 & 19924.39 & 1332.04 \\
12 & 3000 & 41937.89 & 0.444 & 18620.92 & 1244.89 \\
13 & 3000 & 41937.89 & 0.415 & 17402.73 & 1087.45 \\
14 & 3000 & 41937.89 & 0.388 & 16264.23 & 1016.20 \\
15 & 3000 & 41937.89 & 0.362 & 15200.22 & 949.72 \\
16 & 3000 & 41937.89 & 0.339 & 14205.81 & 887.59 \\
17 & 3000 & 41937.89 & 0.317 & 13276.46 & 829.52 \\
18 & 3000 & 41937.89 & 0.296 & 12407.91 & 775.26 \\
19 & 3000 & 41937.89 & 0.277 & 11596.17 & 724.54 \\
20 & 3000 & 41937.89 & 0.258 & 10837.55 & 677.14 \\
21 & 3000 & 41937.89 & 0.242 & 10128.55 & 632.84 \\
22 & 3000 & 41937.89 & 0.226 & 9465.93 & 591.44 \\
23 & 3000 & 41937.89 & 0.211 & 8846.67 & 552.75 \\
24 & 3000 & 41937.89 & 0.197 & 8267.91 & 301513.57 \\
25 & 3000 & 41937.89 & 0.184 & 7727.02 & \\
\hline & & & 488726.63 & 3.62 \\
& & & & & 488726.63 \\
\hline
\end{tabular}

was ₹ 3,01,513.57. Hence, the benefit-cost ratio was estimated to be 1.62. Since B-C ratio was greater than one so the investment was considered to be feasible (See appendix Table 4).

\section{CONCLUSION}

Findings of the study suggested that the installation of 7.5 solar irrigation pump was economically feasible in the long run. However, it is important to note that even after the subsidy, the share of a farmer was still very high. Compound growth rate analysis showed that by providing subsidy, adoption of solar irrigation pump increased. So, it is important on the part of the government to increase the share of subsidy in the total cost of 7.5 solar irrigation pump. Economic viability analysis revealed that solar irrigation pumps were economically feasible. 


\section{REFERENCES}

Food and Agriculture Organization. 2018. India at a glance. www.Fao.Org. http://www.fao.org/india/fao-in-india/ india-at-a-glance/en/. [Last Accessed on 2019, October 27]

Gautam, Y. and Singh, O.P. 2020. Analysis of costs and resource productivity in pearl millet production under solar irrigation system in Jaipur, Rajasthan, J. Pharmacogn. Phytochem., 9(6): 470-472.

Gautam, Y. and Singh, O.P. 2020. Profitability And Resource Utilization in Groundnut Production Under Solar Irrigation System, Int. J. Curr. Microbiol. Appl. Sci., 9(10): 1993-1999.

Gautam, Y. 2020. Economic and environmental impacts of solar irrigation pumps in Rajasthan, India [Doctoral dissertation]. Banaras Hindu University.

Klynveld, P.M.G. 2014. Feasibility analysis for solar agricultural water pumps in India. KPMG Advisory Services Private Limited. https://shaktifoundation.in/wp-content/ uploads/2014/02/feasibility-analysis-for-solar-High-Res-1. pdf [Last Accessed on 2020, January 14]

Ministry of Environment, Forest and Climate Change. 2016. Report of Indian network for climate change assessment. Government of India.

Ministry of Power. 2020. Power sector at a glance all India; 2016. Government of India. https://powermin.nic.in/content/ power-sector-glance-all-india [Last Accessed on 2020, November 04]
National Institution for Transforming India. 2017. Doubling Farmers' Income: Rationale, Strategy, Prospects and Action Plan. NITI Policy Paper No. 1/2017. National Institute for Transformation India, Government of India, New Delhi. http://niti.gov.in/writereaddata/files/document_ publication/ DOUBLING \%20FARMERS\%20INCOME. pdf [Last Accessed on 2020, November 02]

Schock, R.N., Sims, R.E.H., Adegbululgbe, A., Fenhann, J., Konstantinaviciute, I., Moomaw, W., Nimir, H.B., Schlamadinger, B., Torres-Martínez, J., Turner, C., Uchiyama, Y., Vuori, S., Wamukonya, N. and Zhang, X. 2007. Energy supply. In Climate Change 2007: Mitigation. Contribution of Working Group III to the Fourth Assessment Report of the Intergovernmental Panel on Climate Change. Metz, B.; Davidson, O.R.; Bosch, P.R.; Dave, R.; Meyer, L.A. (eds). (pp. 252-322). Cambridge University Press.

Singal, S.K. 2007. Review of augmentation of energy needs using renewable energy sources in India. Renewable and sustainable Energy Reviews, 11(7): 1607-1615.

World Health Organization. Exposure to ambient air pollution; 2017. http://www.who.int/gho/phe/outdoor_ air_pollution/exposure/en/. [Last Accessed on 5 August 2020]. 
